\title{
Regional heterogeneity of human spermatozoa detected with monoclonal antibodies
}

\author{
S. Villarroya and R. Scholler \\ Fondation de Recherche en Hormonologie, 67/77 boulevard Pasteur, 94260 Fresnes, France
}

\begin{abstract}
Summary. The regional antigenic heterogeneity of human spermatozoa is confirmed with 6 monoclonal antibodies raised against ejaculated human spermatozoa. The topographical localization of the antigenic determinants suggests the existence of at least 6 domains on the human spermatozoon. Different fixatives had severe detrimental effects on the antigen-antibody binding. On live human spermatozoa, each antibody bound to a distinct region: acrosome, equatorial segment, entire tail, neck, midpiece and terminal piece. The antigens detected on the acrosome, equatorial segment and entire tail were surface components, whereas the other three were intracellular structures. The determinant present along the entire tail was a sperm-coating antigen. The molecular weights of the recognized antigens were estimated with the Western blot technique.

Immunostaining of individual ejaculates established that the percentages of positive cells were $12-56 \%$ for the acrosome, $8-35 \%$ for the equatorial segment, $90-100 \%$ for the entire tail, $20-52 \%$ for the neck, $9-35 \%$ for the midpiece and $36-90 \%$ for the terminal piece. In addition, labelling of motile and immotile spermatozoa showed differences in the percentages of positive cells, with 5 out of 6 monoclonal antibodies, or in the fluorescence intensity, with the last one labelling the entire tail.
\end{abstract}

\section{Introduction}

The cell surface is of particular interest for interaction with the environment and with other cells (Singer, 1982). The sperm surface membrane is believed to play an active fundamental role in several steps of fertilization, e.g. capacitation, acrosome reaction, binding to the zona pellucida and fusion with the egg plasma membrane (for review, see Yanagimachi, 1981).

Regional heterogeneity of the plasma membrane of mature spermatozoa has been detected for oligosaccharides (Koehler, 1981), proteins (Hjort, Ahuja \& Poulsen, 1982), lipids (Elias, Friend \& Goerke, 1979), surface charges (Yanagimachi, Noda, Fujimoto \& Nicolson, 1972) and arrangements of intramembrane particles (Friend \& Fawcett, 1974; Koehler, 1975; Aguas \& Pinto da Silva, 1983). Monoclonal antibodies (Köhler \& Milstein, 1975) provide a powerful analytical tool, allowing recognition of individual determinants on a complex antigenic structure. These monospecific reagents have been applied to studies in reproductive biology (for review, see Bellvé \& Moss, 1983). Their use as probes of sperm membrane structure has confirmed that the mammalian sperm surface is a dramatic example of cell surface differentiation (Primakoff \& Myles, 1983). Antigens have been identified with monoclonal antibodies on human mature spermatozoa (Lee, Huang, Huang, Hu \& Menge, 1982; Wolf, Sokoloski, Dandekar \& Bechtol, 1983; Yan, Wang, Sato \& Koide, 1983; Kallojoki \& Suominen, 1984; Mettler, Paul, Baukloh \& Feller, 1984). Glassy, Surh \& Sarkar (1984) claimed to recognize antigenically distinct subsets of human spermatozoa with monoclonal antibodies. Isahakia \& Alexander (1984) related monoclonal antibodies with immobilizing and agglutinating properties. Naz, Alexander, Isahakia \& Hamilton (1984) reported an antibody able 
to inhibit binding and penetration of zona-free hamster ova by human spermatozoa. In a preliminary communication (Villarroya \& Scholler, 1984) we described the cytochemical localization of 6 monoclonal antibodies on live human spermatozoa, each one recognizing epitopes on distinct sperm structures (acrosome, equatorial segment, head-tail junction, entire tail, midpiece and terminal piece) and we now report new data obtained with these monoclonal antibodies.

\section{Materials and Methods}

Human sperm preparation. Human ejaculated semen was obtained from out-patients at the Fondation de Recherche en Hormonologie. Normal samples $\left(20-250 \times 10^{6}\right.$ spermatozoa/ml, $>50 \%$ motility and $>60 \%$ normal morphology) were pooled and $1 \mathrm{mM}$-phenylmethane-sulphonyl fluoride (PMSF) was added, as well as in all buffers, to minimize any endogenous protease activity.

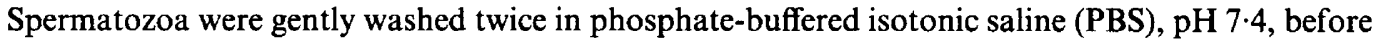
use for immunization and electrophoretic analysis. If spermatozoa were to be used in immunocytochemical studies or in enzyme-linked immunosorbent assay (ELISA), PBS was supplemented with $1 \%$ bovine serum albumin, fraction V (BSA).

Motile spermatozoa were separated from those with no or low motility by the migrationsedimentation method of Tea, Jondet \& Scholler (1983). The percentage of motile spermatozoa was increased up to $98 \%$ with this technique.

Spermatozoa were made permeable by freezing and thawing twice without cryoprotective medium or demembranated by incubation in $0.075 \%$ Triton X-100, 0.075\% Hyamine 2389 (both from Rohm and Haas France S.A., Paris, France) at room temperature $\left(20-22^{\circ} \mathrm{C}\right)$ for $1 \mathrm{~h}$.

Monoclonal antibody production. BALB/c female mice, 4-6 weeks old, were immunized intraperitoneally (i.p.) with $25 \times 10^{6}$ human spermatozoa in $0.1 \mathrm{ml}$ PBS emulsified in an equal volume of Freund's complete adjuvant. Booster injections were given at 2-week intervals. Mice were bled from the tail vein to check the immune response by a solid-phase assay (ELISA, see below). When an adequate immune serum had been raised (positive at a dilution of 1:1000), mice received an i.p. booster injection without adjuvant 4 days before autopsy. Splenocytes were fused with the mouse myeloma cell lines SP $2 / 0$ or NS 1 at the ratio of 10:1 using polyethylene glycol 4000 (Merck), according to the schedule of Fazekas de St Groth \& Scheidegger (1980). The fused cells were selected with 0.05 mM-hypoxanthine (Sigma Chemical Co., St Louis, MO, U.S.A.) and 0.01 mmazaserine (Sigma) in RPMI 1640 medium supplemented with $10 \%$ fetal calf serum, 1 mm-pyruvate, 2 mM-glutamine and antibiotics without feeder layer cells. Hybridoma cells grew in all the wells of 96-well microtitre plates (Costar). The supernatants of confluent cultures were screened for antisperm antibody production with ELISA as described below. Positive cell lines (absorbance higher than 2 standard deviations above the mean of controls) were cloned twice by limiting dilution.

At each stage of culture, positive hybridoma cells were frozen in fetal calf serum containing $10 \%$ dimethylsulphoxide (Sigma) in liquid nitrogen vapour and then transferred to the liquid phase. Antibodies were produced on a larger scale by injection of $10^{7}$ cells into mice primed with pristane $(2,6,10,14$-tetramethylpentadecane; Sigma) to generate ascites fluid as well as by expansion in tissue culture flasks.

Microplate ELISA. Culture supernatants were screened for antibody activity with a solid-phase ELISA using washed human spermatozoa as target cells. Polyvinylchloride 96-well microtitre plates (Dynatech Laboratories, Inc., Alexandria, VA, U.S.A.) were coated with $0.05 \%$ poly-Llysine in PBS $\left(100 \mu \mathrm{l} /\right.$ well) for $1 \mathrm{~h}$ and washed three times with PBS. Then $2 \times 10^{5}$ spermatozoa were placed in individual wells, collected by centrifugation $(400 \mathrm{~g}, 10 \mathrm{~min})$ and then submerged in $0.32 \%$ glutaraldehyde in PBS for $10 \mathrm{~min}$, followed by three washes in PBS. Non-specific binding sites were blocked with $1 \%$ BSA for $1 \mathrm{~h}$. The plates were used immediately or stored at $4^{\circ} \mathrm{C}$. 
Antigen-coated plates were washed in PBS before use. The screening was performed with $100 \mu 1$ of undiluted hybridoma culture supernatants. The second antibody was a 1:1000 dilution of a rabbit peroxidase-conjugated anti-mouse IgG + IgM + IgA (Zymed Laboratories, Burlingame, CA, U.S.A.). After each incubation, carried out at room temperature for $1 \mathrm{~h}$, the plates were washed 4 times in PBS. The bound peroxidase was revealed using $4 \mathrm{~mm}-2,2$-azino-di-(3-ethylbenzthiazoline sulphonate) and $0.02 \%$ hydrogen peroxide in $100 \mathrm{~mm}$-citrate buffer $\mathrm{pH} 5$ as substrate. After incubation for 5-20 min the enzyme reaction was stopped with $2 \mathrm{~mm}$-sodium azide. The absorbance of each well was read at $405 \mathrm{~nm}$ in an automatic plate reader (Titertek Multiskan, Flow Laboratories, Puteaux, France).

Three negative controls were performed for each experiment: (1) preimmune mouse serum in RPMI medium; (2) no antigen; (3) no second antibody. Under our assay conditions, there was no colour reaction in control wells. The polyclonal antiserum of mouse immunized with human spermatozoa (1:10-1:500 dilution) was used as positive control.

Indirect immunofluorescence. The immunofluorescent staining was carried out on fresh living human spermatozoa. Washed cells $\left(20 \times 10^{6} /\right.$ assay $)$ were resuspended in $100 \mu$ of culture supernatant or an ascitic fluid in appropriate dilution for $1 \mathrm{~h}$ and centrifuged $(1000 \mathrm{~g}, 10 \mathrm{~min})$ through $1 \mathrm{ml} \mathrm{PBS,} 1 \%$ BSA. Incubation with a fluorescein isothiocyanate (FITC)-conjugated goat antimouse IgG (Institut Pasteur Production, Marnes la Coquette, France) at a dilution of 1:20 was followed by the same washes. Culture medium or 1\% BSA in PBS served as a negative control. All procedures were performed at room temperature $\left(20-22^{\circ} \mathrm{C}\right)$.

Smears on slides were mounted with a drop of oxidized $p$-phenylenediamine in glycerol diluted with PBS (1:1, v/v) (Oriol \& Mancilla-Jimenez, 1983). Antigenic patterns were visualized with epifluorescence illumination on a Zeiss photomicroscope equipped with filters for 485, 510 and $515 \mathrm{~nm}$. For each preparation, 100 cells or a multiple of 100 were scored. Photographs were taken with Fujichrome 400 ASA film.

Antibody binding patterns were also studied on fixed cells. Human sperm smears were air-dried or fixed in absolute ethanol, acetone, $0.05,0.1$ or $0.3 \%$ glutaraldehyde or $1 \% p$-formaldehyde (made freshly). The slides were then extensively washed and incubations were carried out in a wet chamber.

Nomenclature. Anti-human sperm (a-HS) monoclonal antibodies were named according to the topographical localization of the recognized antigen. Numbers 1 and 2 referred to antibody binding on the head and on the tail respectively. For more restricted antigen localization, this number was followed by a letter: A for acrosome, E for equatorial segment, $\mathrm{P}$ for postacrosome, $\mathrm{N}$ for head-tail connecting piece (the neck), $\mathrm{M}$ for midpiece, $\mathrm{P}$ for principal piece and $\mathrm{T}$ for terminal piece. Then a number was attributed to each particular antibody in the chronological order of their characterization. The corresponding antigen was designated by the same code number preceded by HS for human spermatozoa.

Polyacrylamide gel electrophoresis (PAGE) and protein blot immunobinding assay. Washed human spermatozoa were solubilized directly into the sample buffer (4\% sodium dodecyl sulphate (SDS), w/v, 5\% 2-mercaptoethanol, v/v). Sperm membrane components were also prepared by detergent extraction ( $1 \%$ Triton $\mathrm{X}-100$ or $0.3 \%$ Nonidet $\mathrm{P}-40$ ), acetone precipitation and then solubilization in the sample buffer. SDS slab (1.5 mm thick) PAGE was performed according to the method of Laemmli (1970) under reducing conditions with $10 \%$ running gel and 5\% stacking gel. Gels were calibrated by a protein marker kit for high and low molecular weights (Pharmacia, Uppsala, Sweden).

The electrophoretic protein transfer (Western blot) from gel onto a sheet of $0.45 \mu \mathrm{m}$ pore size nitrocellulose (BA 85 from Schleicher and Schüll GmbH, Dassel, West Germany) was essentially as described by Burnette (1981) except that the transfer buffer contained $0.01 \%$ SDS and the blotting was accomplished at $0.7 \mathrm{~A}$ for $2 \mathrm{~h}$ in a Transphor (LKB, Bromma, Sweden) apparatus. The protein 
transfer efficiency was checked by: (1) staining a strip of the gel before and after the transfer with Coomassie brilliant blue R 250 in methanol:acetic acid:water (45:10:45, by vol.) and destaining in methanol:acetic acid:water (20:10:70, by vol.) until clear, and (2) visualization of unlabelled blotted proteins with Aurodye (Janssen Life Sciences Products, Beerse, Belgium).

For immunostaining the protein binding sites were saturated with $3 \%$ BSA in PBS for $2 \mathrm{~h}$. The nitrocellulose paper was cut into $0.4 \mathrm{~cm}$ strips, incubated with different hybridoma supernatants overnight in sealed plastic bags and then flooded with a 1:100 dilution of peroxidase-conjugated goat anti-mouse IgG (Institut Pasteur Production, Marne la Coquette, France). All incubations were performed at room temperature $\left(20-22^{\circ} \mathrm{C}\right)$; after each incubation, blots were washed with rocking for $40 \mathrm{~min}$ in 4 changes of PBS. Bound peroxidase was detected with $1.5 \mathrm{~mm}$-3,3'-diaminobenzidine or $3 \mathrm{mM}$-4-chloro-1-naphthol (dissolved in $20 \%$ methanol), both in

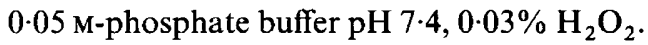

\section{Results}

\section{Monoclonal antibody production}

Between 1 and $12 \%$ of microtitre plate wells from the different splenocytes $\times$ myeloma fusions were found to secrete antibodies to human spermatozoa when screened by solid-phase ELISA. Some positive clones lost their antibody activity before or after freezing in liquid nitrogen. Nevertheless, 23 independently derived clones were established and remained positive on the ELISA screening test. They were all screened on human spermatozoa by indirect immunofluorescence; some supernatants positive in ELISA did not show any fluorescence.

\section{Topographical localization of the antigenic targets}

Based upon the results of the indirect immunofluorescence assay with live human spermatozoa, 6 monoclonal antibodies, all of the IgG class, were selected for further investigation. Their binding was limited to specific regions of the cells and the patterns are shown in Fig. 1.

Spermatozoa labelled with a-HS 1A.1 had its acrosome outlined or fluorescent spots scattered over the anterior head, revealing a patchwork quilt-like topography of the acrosome. The equatorial segment was recognized by a-HS 1E.1. Antibody a-HS 2.1 bound, with a patchy distribution, along the entire length of the tail. Exposure of live spermatozoa to this antibody resulted in tail-to-tail agglutination, along their entire length, dependent upon the antibody concentration. Three monoclonal antibodies stained different regions of the tail. Antibody a-HS 2 N.1 displayed a fluorescent pattern sharply delimited to the head-tail connecting piece (the neck). The midpiece, where the mitochondria are located, was recognized by a-HS 2 M.1. Antibody a-HS 2 T.1 showed intense, homogeneous fluorescence over the terminal piece.

Azide-treated spermatozoa exhibited the same patterns. Spermatozoa failed to show fluorescence when PBS was substituted for the first antibody. The polyclonal positive control antiserum, obtained from mice immunized with whole spermatozoa, was positive on the head and tail.

Experiments performed with individual ejaculates confirmed that different percentages of spermatozoa were stained by all but one of the monoclonal antibodies. Antibody a-HS 2.1, binding to the entire tail, was the only one to recognize virtually all spermatozoa. The remaining 5 monoclonal antibodies reacted only with certain percentages of spermatozoa and for each antibody immunostaining of spermatozoa from different donors established the existence of interindividual differences in the percentage of positive cells. Table 1 shows the average percentage of stained spermatozoa and the range for each antibody. There was no evident correlation between the percentage of positive cells, labelled with each of the 5 antibodies, and such physiological sperm characteristics as motility, concentration and cytology. 
Table 1. Percentages of live spermatozoa from 14 individual ejaculates, stained with each of the 6 monoclonal antibodies

\begin{tabular}{lccc}
\hline & & \multicolumn{2}{c}{ Percentage of labelled cells } \\
\cline { 3 - 4 } $\begin{array}{l}\text { Monoclonal } \\
\text { antibody }\end{array}$ & $\begin{array}{c}\text { Target } \\
\text { localization }\end{array}$ & Mean $(n=14)$ & Range \\
\hline a-HS 1A.1 & Acrosome & 35 & 12.56 \\
a-HS 1E.1 & Equatorial segment & 25 & $8-35$ \\
a-HS 2.1 & Tail & 97 & $90-100$ \\
a-HS 2N.1 & Neck & 30 & $20-52$ \\
a-HS 2M.1 & Midpiece & 20 & $9-35$ \\
a-HS 2T.1 & Terminal piece & 50 & $36-90$ \\
\hline
\end{tabular}
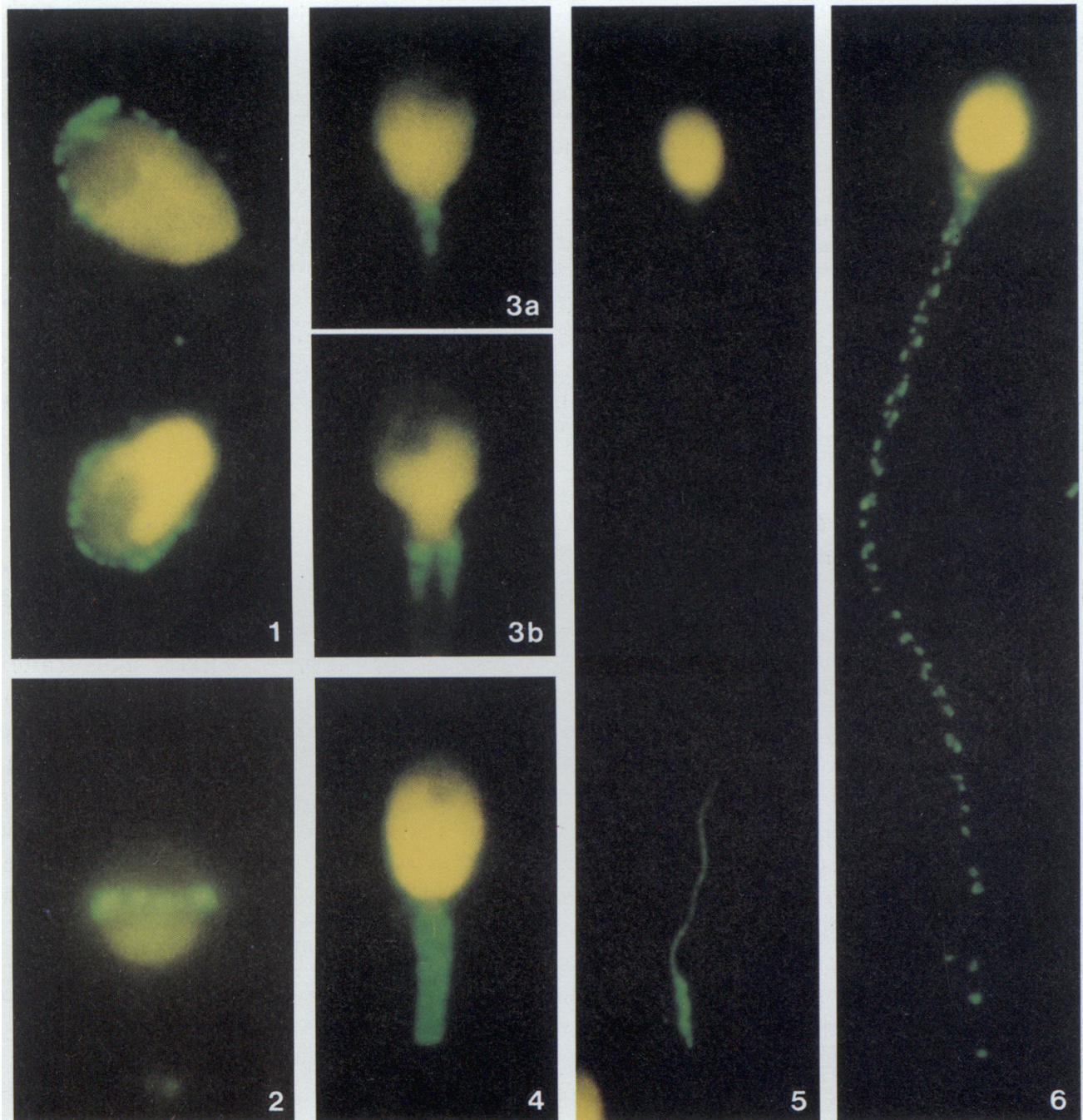

Fig. 1. Localization of antigenic targets on live human spermatozoa with monoclonal antibodies. The yellow-orange staining of nuclei is produced by $p$-phenylenediamine. FITCconjugated goat anti-mouse IgG serum demonstrated the binding patterns of: (1) a-HS IA.I (acrosome); (2) a-HS 1E.I (equatorial segment); (3) a-HS 2N.1 (neck); 3a, normal spermatozoon; 3b, spermatozoon with a double flagellum: (4) a-HS 2M.1 (midpiece); (5) a-HS 2T.1 (terminal piece); (6) a-HS 2.1 (tail). Negative control (not shown) was not FITCfluorescent. Magnification $\times 9000$ (for 1,2.3 and 4) and $\times 5000$ (for 5 and 6). 


\section{Effect of different fixatives on the antibody patterns}

Almost all fixatives and even air-drying consistently modified the fluorescent pattern of all 6 monoclonal antibodies. Fixation of suspended cells in $1 \% p$-formaldehyde was less damaging than fixing them on smears, except for antibody 2 N.1, the fluorescence reaction of which was abolished (Table 2). The glutaraldehyde-containing fixatives had a detrimental effect on the binding of all 6 antibodies, increasing progressively with the concentrations of glutaraldehyde (Table 2). Blocking of free radicals on glutaraldehyde-fixed cells with $20 \mathrm{~mm}$-glycine in PBS did not change either patterns or percentages of positive reactions. Fixation with absolute ethanol or acetone or by airdrying also induced severe changes in the 6 antibody fluorescent patterns (Table 2). Therefore all experiments were carried out with live human spermatozoa.

Table 2. Monoclonal antibody patterns on human spermatozoa fixed under different protocols

\begin{tabular}{|c|c|c|c|c|c|c|}
\hline \multirow[b]{2}{*}{ Fixatives } & \multicolumn{6}{|c|}{ Monoclonal antibody patterns and percentages of labelled cells } \\
\hline & $1 A .1$ & 1E.1 & 2.1 & $2 N .1$ & $2 \mathrm{M} .1$ & $2 \Upsilon .1$ \\
\hline $\begin{array}{l}\text { Live sperm. } \\
\text { (in suspension) }\end{array}$ & $\begin{array}{c}\text { Acrosome } \\
40 \%\end{array}$ & $\begin{array}{c}\text { Equatorial } \\
\text { segment } \\
26 \%\end{array}$ & $\begin{array}{c}\text { Tail } \\
\text { (patchy) } \\
100 \%\end{array}$ & $\begin{array}{l}\text { Neck } \\
50 \%\end{array}$ & $\begin{array}{l}\text { Midpiece } \\
36 \%\end{array}$ & $\begin{array}{c}\text { Terminal } \\
\text { piece } \\
74 \%\end{array}$ \\
\hline $\begin{array}{l}1 \% p- \\
\text { formaldehyde } \\
\text { (in suspension) }\end{array}$ & $\begin{array}{c}\text { Acrosome } \\
60 \%\end{array}$ & $\begin{array}{c}\text { Equatorial } \\
\text { segment } \\
40 \%\end{array}$ & $\begin{array}{l}\text { As live } \\
\text { sperm. }\end{array}$ & None & $\begin{array}{l}\text { As live } \\
\text { sperm. }\end{array}$ & $\begin{array}{l}\text { As live } \\
\text { sperm. }\end{array}$ \\
\hline $\begin{array}{l}1 \% p- \\
\text { formaldehyde }\end{array}$ & $\begin{array}{l}\text { As live } \\
\text { sperm. }\end{array}$ & None & $\begin{array}{c}\text { Head and } \\
\text { tail } \\
100 \%\end{array}$ & None & None & None \\
\hline $\begin{array}{l}0.01 \% \\
\text { glutaraldehyde }\end{array}$ & $\begin{array}{c}\text { Acrosome } \\
\text { (very weak) } \\
8 \%\end{array}$ & $\begin{array}{l}\text { As live } \\
\text { sperm. }\end{array}$ & $\begin{array}{c}\text { Tail (patchy) } \\
\text { and acrosome } \\
100 \%\end{array}$ & $\begin{array}{l}\text { As live } \\
\text { sperm. }\end{array}$ & $\begin{array}{l}\text { Tail } \\
40 \%\end{array}$ & $\begin{array}{c}\text { Tail } \\
100 \%\end{array}$ \\
\hline $\begin{array}{l}0.1 \% \\
\text { glutaraldehyde }\end{array}$ & $\begin{array}{c}\text { As } 0.01 \% \\
\text { glutaraldehyde }\end{array}$ & $\begin{array}{c}\text { Tail } \\
100 \%\end{array}$ & $\begin{array}{l}\text { Tail and } \\
\text { acrosome } \\
100 \%\end{array}$ & $\begin{array}{l}\text { As } 0.01 \% \\
\text { glutaral- } \\
\text { dehyde }\end{array}$ & $\begin{array}{l}\text { As 0.01\% } \\
\text { glutaral- } \\
\text { dehyde }\end{array}$ & $\begin{array}{c}\text { As } 0.01 \% \\
\text { glutaral- } \\
\text { dehyde }\end{array}$ \\
\hline $\begin{array}{l}0 \cdot 3 \% \\
\text { glutaraldehyde }\end{array}$ & $\begin{array}{c}\text { Postacrosome } \\
\text { and tail } \\
\text { (patchy) } \\
100 \%\end{array}$ & $\begin{array}{c}\text { Head and } \\
\text { tail } \\
100 \%\end{array}$ & $\begin{array}{c}\text { Head and } \\
\text { tail } \\
100 \%\end{array}$ & $\begin{array}{c}\text { Tail } \\
100 \%\end{array}$ & $\begin{array}{l}\text { Midpiece } \\
40 \%, \\
\text { acrosome } \\
100 \%\end{array}$ & $\begin{array}{c}\text { Head and } \\
\text { tail } \\
100 \%\end{array}$ \\
\hline $\begin{array}{l}\text { Absolute } \\
\text { ethanol }\end{array}$ & $\begin{array}{c}\text { Acrosome } \\
\text { (very weak) } \\
10 \%\end{array}$ & $\begin{array}{c}\text { Principal } \\
\text { tail } \\
100 \%\end{array}$ & $\begin{array}{c}\text { Tail } \\
\text { (weak) } \\
100 \%\end{array}$ & $\begin{array}{c}\text { As } 0.3 \% \\
\text { glutaral- } \\
\text { dehyde, but } \\
\text { stronger }\end{array}$ & $\begin{array}{l}\text { Midpiece } \\
80 \%\end{array}$ & $\begin{array}{c}\text { Principal } \\
\text { tail } \\
100 \%\end{array}$ \\
\hline Acetone & $\begin{array}{c}\text { Acrosome } \\
\text { (weak) } \\
30 \%\end{array}$ & $\begin{array}{c}\text { Tail } \\
\text { (weak) } \\
(100 \%)\end{array}$ & $\begin{array}{c}\text { Head and } \\
\text { tail } \\
100 \%\end{array}$ & $\begin{array}{l}\text { As live } \\
\text { sperm. }\end{array}$ & $\begin{array}{c}\text { Tail } \\
100 \%\end{array}$ & None \\
\hline Air-dried & None & $\begin{array}{c}\text { Equatorial } \\
\text { segment } \\
20 \%, \\
\text { acrosome } \\
80 \%\end{array}$ & $\begin{array}{c}\text { Tail and } \\
\text { postacrosome } \\
100 \%\end{array}$ & As ethanol & None & $\begin{array}{c}\text { Tail } \\
100 \%\end{array}$ \\
\hline
\end{tabular}

Incubations with first and second antibodies were carried out on slides unless otherwise stated. 'Tail' is employed for the entire tail and 'prinicipal tail' for tail without midpiece. The patchy distribution of the fluorescent marker is mentioned; if not, the distribution was homogeneous. 
Fluorescent labelling of damaged spermatozoa

Two types of modifications were observed after in-vitro induction of membrane damage. Permeabilization and demembranation had comparable effects on the fluorescent pattern of each antibody. The immunostaining was strongly diminished with 3 antibodies (a-HS 1A.1, a-HS 1E.1 and a-HS 2.1), but a clear-cut increase of the fluorescent labelling was observed with the other three antibodies (a-HS 2N.1, a-HS 2M.1 and a-HS 2T.1). This increase in staining was manifested both by a higher percentage of positive cells (100\% for a-HS 2 M.1 and a-HS 2T.1, but less than $100 \%$ for a-HS $2 \mathrm{~N} .1$ ) and by an increase of the tail area stained with a-HS 2M.2 for permeabilized spermatozoa and a-HS 2T.1 for permeabilized and demembranated spermatozoa. Data from three experiments are shown in Table 3 .

Table 3. Effect of membrane damages induced by detergent (demembranation) or freezing and thawing (permeabilization) on the fluorescent staining of live human spermatozoa with the different monoclonal antibodies (mean percentages from 3 experiments)

\begin{tabular}{lccc}
\hline \multirow{2}{*}{$\begin{array}{l}\text { Monoclonal } \\
\text { antibody }\end{array}$} & \multicolumn{3}{c}{ Antigen localization and percentage of labelled cells } \\
\cline { 2 - 4 } & Untreated control & Demembranated spermatozoa & Permeabilized spermatozoa \\
\hline a-HS 1A.1 & Acrosome (24\%) & None & None \\
a-HS 1E.1 & Equatorial segment (17\%) & None & None \\
a-HS 2.1 & Tail $(100 \%)$ & None & Tail (weak) $(50 \%)$ \\
a-HS 2N.1 & Neck (42\%) & Neck $(68 \%)$ & Neck $(80 \%)$ \\
a-HS 2M.1 & Midpiece $(33 \%)$ & Midpiece $(100 \%)$ & Entire tail (100\%) \\
a-HS 2T.1 & Terminal piece (70\%) & Entire tail $(100 \%)$ & Entire tail $(100 \%)$ \\
\hline
\end{tabular}

Incubation of the sperm suspension with $50 \mu \mathrm{g}$ trypsin $/ \mathrm{ml}$ at room temperature $\left(20-22^{\circ} \mathrm{C}\right)$ for $1 \mathrm{~h}$, before the antigen-antibody reaction, increased three times the percentage of cells labelled with a-HS 1A.I. This enzymic digestion also changed the staining pattern of the a-HS 2T.1 antibody: the entire tail became positive whereas only the terminal piece was positive for the untreated control.

When the whole ejaculate was kept without PMSF for $4 \mathrm{~h}$ at $37^{\circ} \mathrm{C}$ before sperm processing, only the cells stained with a-HS 1E.1 exhibited a reduction (2-fold) in the percentage of positive cells. Human seminal plasma proteases had no detrimental effect on the other 5 monoclonal antibodies.

\section{Differential labelling of motile and immotile spermatozoa}

Two distinct populations, containing highly motile or low- and non-motile spermatozoa, were obtained from whole ejaculates using the migration-sedimentation apparatus devised by Tea $e t$ al. (1983). Labelling was performed on aliquants allowed to migrate for $3 \mathrm{~h}$. Controls consisted of immunostaining of an aliquant removed before migration (control $0 \mathrm{~h}$ ) or an aliquant of whole spermatozoa kept in seminal plasma or $\mathrm{B}_{2}$ medium (in which the migration was accomplished) or a mixture of both under similar conditions of temperature and time (control $3 \mathrm{~h}$ ). There was no difference between these controls.

The same pattern was seen on the motile and immotile spermatozoa with all 6 monoclonal antibodies, but the intensity of the fluorescent marker for a-HS 2.1 or the size of the positive subpopulation for the other 5 antibodies were different in these two types of sperm samples.

Antibodies labelling the equatorial segment (a-HS 1E.1) and the three discrete tail regions (a-HS 2N.1, a-HS 2M.1 and a-HS 2T.1) stained preferentially, 4-10 times more frequently, spermatozoa with no, or low, motility without any increase in the percentage of positive cells compared with the controls (Table 4). However, the HS 1A.1 antigen was mainly distributed on 
Table 4. Distribution, as detected by indirect immunofluorescence, of the monoclonal antibody targets on spermatozoa with different motility

\begin{tabular}{lccc}
\hline & \multicolumn{3}{c}{ Percentage of labelled cells (mean of 5 experiments and range) } \\
\cline { 2 - 4 } $\begin{array}{l}\text { Monoclonal antibody } \\
\text { (localization of } \\
\text { the antigen) }\end{array}$ & $\begin{array}{c}\text { Spermatozoa before } \\
\text { migration }\end{array}$ & \multicolumn{2}{c}{ Spermatozoa after 3h migration } \\
\hline $\begin{array}{l}\text { 1A.1 } \\
\text { (acrsome) }\end{array}$ & $\begin{array}{c}36 \\
(23-55)\end{array}$ & $\begin{array}{c}77 \\
(60-92)\end{array}$ & $\begin{array}{c}24 \\
(6-35)\end{array}$ \\
\hline $\begin{array}{l}\text { 1E.1 } \\
\text { (equatorial segment) }\end{array}$ & $\begin{array}{c}28 \\
(21-38)\end{array}$ & $\begin{array}{c}6 \\
(2-8)\end{array}$ & $\begin{array}{c}25 \\
(18-35)\end{array}$ \\
\hline $\begin{array}{l}2 \mathrm{~N} .1 \\
\text { (neck) }\end{array}$ & $\begin{array}{c}26 \\
(21-29)\end{array}$ & $\begin{array}{c}5 \\
(0-8)\end{array}$ & $\begin{array}{c}25 \\
(18-34)\end{array}$ \\
\hline $\begin{array}{l}2 \mathrm{M} .1 \\
\text { (midpiece) }\end{array}$ & $\begin{array}{c}21 \\
(10-26)\end{array}$ & $\begin{array}{c}2 \\
(2-4)\end{array}$ & $\begin{array}{c}18 \\
(10-25)\end{array}$ \\
\hline $\begin{array}{l}5 \mathrm{~T} .1 \\
\text { (terminal piece) }\end{array}$ & $\begin{array}{c}56-76) \\
(40)\end{array}$ & $\begin{array}{c}13 \\
(8-19)\end{array}$ & $\begin{array}{c}55 \\
(37-74)\end{array}$ \\
\hline $\begin{array}{l}\text { 2.1 } \\
\text { (tail) }\end{array}$ & $\begin{array}{c}100 \\
\text { (strong and weak }\end{array}$ & $\begin{array}{c}\text { (strong patchy } \\
\text { distribution) }\end{array}$ & $\begin{array}{c}\text { (weak patchy } \\
\text { distribution) }\end{array}$ \\
\hline
\end{tabular}

the acrosome of motile spermatozoa. There was a net (2-3 times) increase, in comparison with the control, in the percentage of positive highly motile spermatozoa, whereas the percentage of positive low- and non-motile spermatozoa remained unchanged or slightly lower than the control (Table 4). The percentage of fluorescent highly motile gametes was augmented with increasing time of migration, as shown by experiments in which aliquants of the same sperm sample were allowed to migrate for different periods. For the motile population, the labelled cells represented $43 \%$ ( $30 \mathrm{~min}$ migration), $64 \%$ ( $1 \mathrm{~h} 30 \mathrm{~min}$ migration) and $77 \%$ ( $3 \mathrm{~h}$ migration), whereas the percentages in the immotile population were $17 \%, 21 \%$ and $19 \%$, respectively, and $23 \%$ in the controls.

The antibody a-HS 2.1, even though staining almost all cells in both populations, had different patchy distribution: very strong intense fluorescence for the motile spermatozoa but weak for the immotile spermatozoa. Both patterns, strong and weak, could be seen in the controls.

\section{Molecular nature of the identified antigens}

The electrophoretic pattern of detergent-extracted sperm membrane components showed some losses in low as well as in high molecular weight protein bands. Consequently, all experiments were carried out with washed spermatozoa solubilized directly in the sample buffer. During the electrotransfer from the polyacrylamide gel to the nitrocellulose sheet these membrane proteins had a tendency to reprecipitate. Therefore, to improve this transfer $0.01 \% \operatorname{SDS}(\mathrm{w} / \mathrm{v})$ was included in the transfer buffer. The antigen-antibody complexes were revealed with 3,3'-diaminobenzidine or 4-chloro-1-naphthol. Sensitivity of both was almost similar in our hands.

Monoclonal antibody a-HS 1A.1 apparently did not identify any protein band. Antibody a-HS $1 \mathrm{E} .1$ recognized one major and two minor protein bands, with $M_{\mathrm{r}}$ values of 53000,56000 and 73000 respectively. Antibody a-HS 2.1 reacted with two proteins $\left(M_{\mathrm{r}} 27000\right.$ and 59000$)$ as well as with a diffuse spot spreading from 0 to $M_{\mathrm{r}} 25000$. This spot was not visualized when polyacrylamide gels were stained with Coomassie brilliant blue or Schiff's reagent. Antibody a-HS $2 \mathrm{~N} .1$ recognized, with a wide range of intensities, many antigens having molecular weights from 

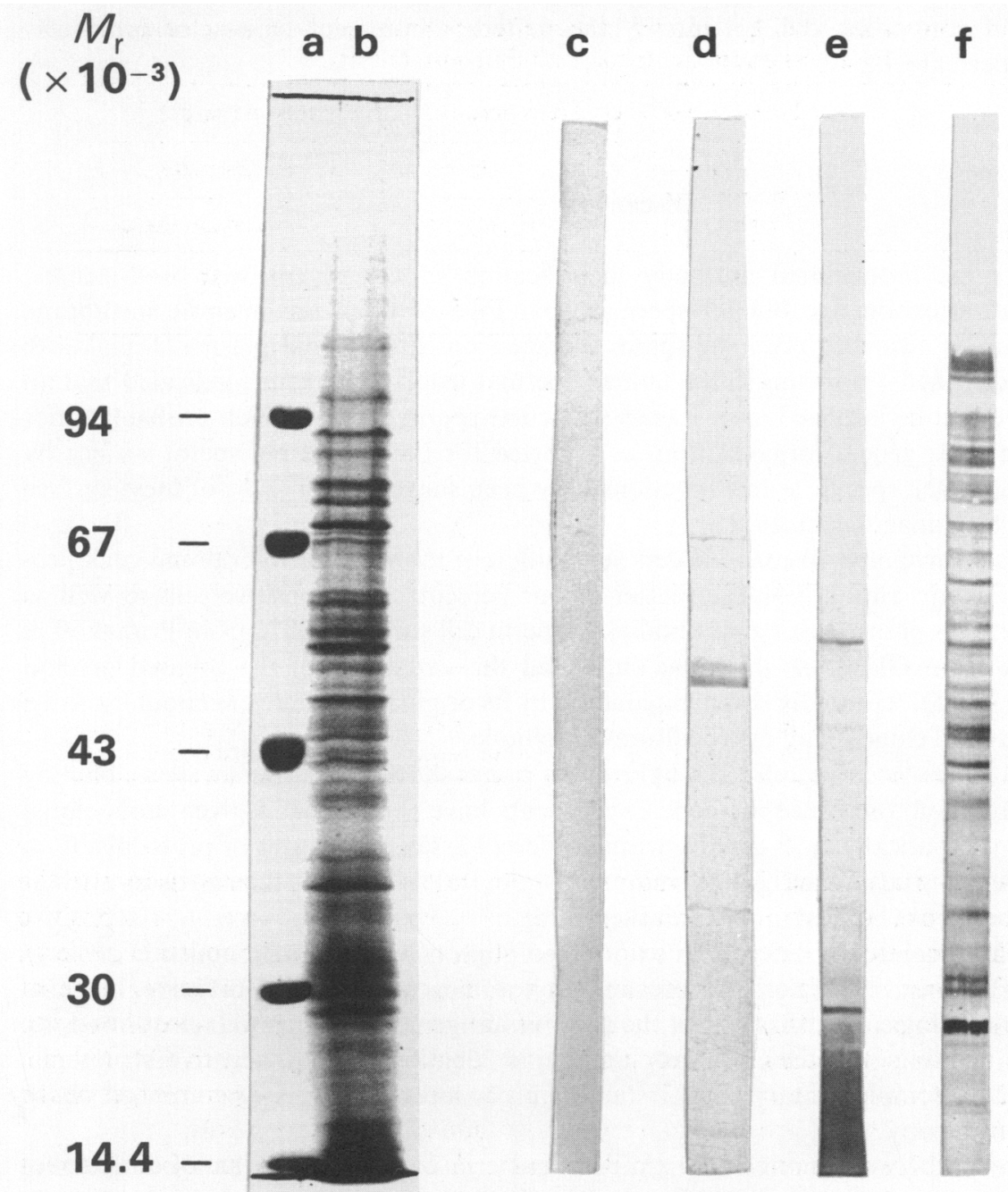

g

h

Fig. 2. Identification of human sperm antigens by immunostaining of Western blots. Molecular weight protein marker kit (a) and solubilized sperm proteins (b) were submitted to SDS-PAGE and stained for protein with Coomassie brilliant blue. After transfer to nitrocellulose antigens were detected with monoclonal antibodies a-HS 1A.1 (c), a-HS 1E.1 (d), a-HS 2.1 (e), a-HS 2N.1 (f), a-HS 2M.1 (g) and a-HS 2T.1 (h).

26000 to 105000 . A broad band with $M_{\mathrm{r}} 32000$ and a band of $M_{\mathrm{r}} 83000$ reacted with a-HS 2M.1. Antibody a-HS 2T.1 developed two very sharp bands $\left(M_{\mathrm{r}} 114000\right.$ and 130000$)$. Typical results of immunorevealed protein blots are shown in Fig. 2.

When human seminal plasma was used instead of sperm membrane, no staining of the nitrocellulose was obtained, with the only exception of the a-HS 2.1 monoclonal antibody which reacted with the same low molecular weight spot.

\section{Presence of sperm-coating antigens}

Incubation of detergent-treated spermatozoa in human seminal plasma restored the abolished fluorescent pattern of the antibody a-HS 2.1. The same incubation, followed by staining with the 
other 5 monoclonal antibodies, did not modify the pattern, fluorescent or not, of previously detergent-treated spermatozoa.

\section{Discussion}

This paper reports the monoclonal antibody identification of 6 antigens with well defined topographical localization on live human spermatozoa. Five of them are intrinsic membrane components and one is adsorbed onto the sperm surface from the seminal plasma. Isahakia \& Alexander (1984) identified 4 domains in the human spermatozoon. Our results indicated that an individual antigen could be localized in at least 6 particular sperm regions which probably differ from each other in their general organization, as reported for the guinea-pig sperm surface by Primakoff \& Myles (1983); specific sperm functions have been suggested for some of these surface domains (reviewed by Yanagimachi, 1981).

The splenocytes $\times$ myeloma fusions yielded very different numbers of hybridoma cells producing anti-human sperm antibodies. The scatter of our percentages of positive cells as well as those from other reports of monoclonal antibodies to sperm cell surfaces ( $38 \%$ from Primakoff $\&$ Myles, 1983; $2 \cdot 8 \%$ from Glassy et al., 1984) illustrated the variability of the original method (Köhler \& Milstein, 1975), repeatedly commented upon by its originators: there are about the same odds of obtaining hybrid clones in all microcultures or in none.

Only 6 of the 23 stable, positive in ELISA hybridoma clones showed anti-human sperm binding with an indirect immunofluorescence method. Experiments have shown that a given monoclonal antibody may vary dramatically in its activity within different assay procedures or protocols. If an antibody is to be used to study an antigen by immunohistological techniques, then an assay such as immunofluorescence should be used in the initial screening.

Mounting immunofluorescent slides in an oxidized solution of $p$-phenylenediamine in glycerol (Oriol \& Mancilla-Jimenez, 1983) not only prevented photobleaching of the FITC dye, but also facilitated excellent cytological localization of the positive antigenic targets as well as allowed, by the yellow-orange staining of nuclei, an easy and rapid identification of negative structures, without the use of any complementary counterstaining procedures for nuclei or combined phase and fluorescence microscopy.

When a comparison between monoclonal antibody patterns on live and methanol or acetonefixed human spermatozoa was reported, either similar (Isahakia \& Alexander, 1984; Naz et al., 1984) or modified (Kallajoki \& Suominen, 1984) staining patterns have been observed. Our experiments showed drastic and unpredictable changes in the labelling with the 6 monoclonal antibodies after different fixatives. Different antigenic determinants may react variably to different fixation protocols (Hancock, Becker \& Atkins, 1982; Van Ewijk, Van Soest, Verkerk \& Jongkind, 1984; Walker, Beelan, Buckley, Melvin \& Yen, 1984). Some determinants may be partly or totally destroyed by exposure to standard fixatives; insertion of fixative molecules to glycoproteins or glycolipids may have a masking effect on antigenic determinants; due to cross-linking, the antigen tertiary structure may be deformed in such a way that the binding site of the antibody molecule no longer recognizes its three-dimensional shape; additional determinants, both within the cell membrane and intracellular, may become available for binding. Glutaraldehyde severely affects the binding of our monoclonal antibodies. This fixative, commonly used in hybridoma screening assays, could be avoided in the preparation of cell-coated microtitration plates (Epstein \& Lunney, 1985).

The acrosomic HS 1A.1 antigen is actually located on the sperm plasma membrane. It is expressed only in a certain percentage of the ejaculated human spermatozoa. There probably exists in the ejaculate various populations of cells at different maturation stages, carrying different antigens on their surface as a result of the continuous processing of the sperm membrane during 
spermatogenesis, epididymal maturation or after ejaculation (for recent review, see Bellvé \& O'Brien, 1983). Another possibility is that some spermatozoa express the relevant determinant at too low a density to be detected by immunocytochemistry.

The antibody a-HS $1 \mathrm{~A} .1$ is the only one to stain preferentially the motile spermatozoa. The corresponding antigen might be a marker of achieved maturation. Another possibility is that new determinants, related to capacitation, become available for binding on the surface after surface changes have occurred; it is also possible that the presence of surface molecules, disappearing during capacitation, might sterically hinder the attachment of the antibody. Such capacitation phenomena could explain the increase of the positive cells after trypsin treatment (Shinohara, Yanagimachi \& Srivastava, 1985) and this is apparently corroborated by the fact that longer migration, and consequently longer incubation in the capacitation medium, increased the percentage of labelled cells. Further experiments are needed to assess the exact role of this antigen, but we already feel that the antibody a-HS $1 \mathrm{~A} .1$ should be a good candidate for testing the role of regional functions of the acrosome during fertilization. The acrosome is involved in some steps of sperm capacitation and the consequent acrosome reaction, a prerequisite of fertilization (Stambaugh, 1978; O'Rand, 1982). Despite similar immunofluorescence staining patterns, monoclonal antibodies revealed the structural complexity of the anterior head which contains more than one antigenic system (Lee et al., 1982; Isahakia \& Alexander, 1984; Kallajoki \& Suominen, 1984). Antibody a-HS 1A.1 failed to react with any sperm components in the Western blots. The conditions used for electrophoresis might lead to destruction of antigenic determinants, causing loss of immunoreactivity with the target antigen (Thorpe, Bird \& Spitz, 1984).

The antibody a-HS 1E.1 reacted with protein located on the sperm surface around the equatorial segment. Protein with the same localization, but with different molecular weight, was reported by Isahakia \& Alexander (1984). Baccetti, Burrini \& Linnet (1981) found the same pattern for anti-human sperm antiserum from vasectomized men. Therefore, several distinct antigenic determinants seem to be present in the equatorial segment which has been suggested as possible site of initial sperm egg contact and fusion (Noda \& Yanagimachi, 1976).

The HS 2.1 antigen is localized on the sperm surface over the entire tail length. The low molecular weight component, migrating as a broad spot in PAGE, is a sperm-coating antigen. Unexpectedly, this sperm-coating antigen was more strongly and more intensely fluorescent in highly motile spermatozoa which had left the seminal plasma to migrate through the $\mathbf{B}_{2}$ medium than in those remaining in the plasma.

The antibody a-HS 2N.1 labelled an intracellular determinant in the neck. Live swimming spermatozoa presumably have an intact plasma membrane that does not allow the penetration of antibody molecules. However, they may permeate into the cell through small breaks in the plasma membrane of damaged spermatozoa to detect intracellular antigens, as demonstrated by Jones, Brown, Cran \& Gaunt (1983). Baccetti et al. (1981) reported that human antiserum stained the striated columns. On protein blots this antibody revealed, with different intensities, many antigens within a very broad range of molecular weights. The repeated demonstration of cross-reacting sites, a striking revelation of recent experiments with monoclonal antibodies, has been discussed by Lane \& Koprowsky (1982). As they stated, reaction with a monoclonal antibody cannot itself be interpreted as proving molecular identity.

Two other antibodies (a-HS 2M.1 and 2T.1) recognized intracellular antigens. The percentage of positive cells is not indicative of the antigen location; an antibody labelling less than one third of the cells as well as another labelling most of them recognized both intracellular antigens. In addition, these two antibodies were able to bind to the entire tail length of damaged spermatozoa, apparently recognizing two antigenic determinants with very different molecular weights. An alternative possibility is that one of these monoclonal antibodies may recognize a site common to two different antigens and in some models there is no reason to assume any biological relationship between the cross-reacting antigens (Lane \& Koprowsky, 1982). These two antibodies, as well as the a-HS 2 N.1, should be very useful reagents for assessing tail membrane integrity and the damage 
induced by sperm cryopreservation, which has been reported to cause surface changes (Alexander \& Kay, 1977).

These first results and the obvious usefulness of monoclonal antibodies as monospecific probes has encouraged us to extend our hybridoma library to enlighten the human sperm "antigenic nightmare" (Jones, 1980), to dissect the structure of the sperm membrane and determine the role of its components in human gametogenesis and fertilization.

We thank Dr R. A. P. Harrison for encouragement, Dr R. Oriol and Dr J. Grenier for critical reading of the manuscript, and $\operatorname{Dr} \mathbf{M}$. Jondet for discussions.

\section{References}

Aguas, A.P. \& Pinto da Silva, P. (1983) Regionalization of transmembrane glycoproteins in the plasma membrane of boar sperm head is revealed by fracture-label. J. Cell Biol. 97, 1356-1364.

Alexander, N.J. \& Kay, R. (1977) Antigenicity of frozen and fresh spermatozoa. Fert. Steril. 28, 1234-1237.

Baccetti, B., Burrini, A.G. \& Linnet, L. (1981) Submicroscopic localization of human sperm antibodies. $J$. Submicrosc. Cytol. 13, 649-656.

Bellvé, A.R. \& Moss, S.B. (1983) Monoclonal antibodies as probes of reproductive mechanisms. Biol. Reprod. 28, 1-26.

Bellvé, A.R. \& O'Brien, D.A. (1983) The mammalian spermatozoon: structure and temporal assembly. In Mechanism and Control of Animal Fertilization, pp. 55-137. Ed. J. F. Hartman. Academic Press, New York.

Burnette, W.N. (1981) 'Western blotting': electrophoretic transfer of proteins from sodium dodecyl sulfatepolyacrylamide gels to unmodified nitrocellulose and radiographic detection with antibody and radioiodinated protein A. Analyt. Biochem. 112, 195-203.

Elias, M.P., Friend, D.S. \& Goerke, J. (1979) Membrane sterol heterogeneity: freeze fracture detection with saponins and filipin. J. Histochem. Cytochem. 27, 1247-1260.

Epstein, S.L. \& Lunney, J.K. (1985) A cell surface ELISA in the mouse using only poly-L-lysine as cell fixative. J. Immunol. Meth. 76, 63-72.

Fazekas de St Groth, S. \& Scheidegger, D. (1980) Production of monoclonal antibodies: strategy and tactics. J. Immunol. Meth. 35, 1-21.

Friend, D.S. \& Fawcett, D.W. (1974) Membrane differentiation in freeze-fractured mammalian sperm. $J$. Cell Biol. 63, 641-664.

Glassy, M.C., Surh, C.D. \& Sarkar, S. (1984) Murine monoclonal antibodies that identify antigenically distinct subpopulations of human sperm. Hybridoma 3, 363-371.

Hancock, W.W., Becker, G.J. \& Atkins, R.C. (1982) A comparison of fixatives and immunohistochemical technics for use with monoclonal antibodies to cell surface antigens. Am. J. Clin. Path. 78, 825-831.

Hjort, T., Ahuja, S.P. \& Poulsen, F. (1982) Studies on sperm membrane antigens. In Immunological Factors in Human Reproduction, pp. 77-90. Eds S. Shulman, F. Dondero \& M. Nicotra. Academic Press, London.
Isahakia, M. \& Alexander, N.J. (1984) Interspecies crossreactivity of monoclonal antibodies directed against human sperm antigens. Biol. Reprod. 30, 1015-1026.

Jones, R., Brown, C.R., Cran, D.G. \& Gaunt, S.J. (1983) Surface and internal antigens of rat spermatozoa distinguished using monoclonal antibodies. Gamete Res. 8, 255-265.

Jones, W.R. (1980) Immunologic infertility-fact or fiction? Fert. Steril. 33, 577-586.

Kallajoki, M. \& Suominen, J. (1984) An acrosomal antigen of human spermatozoa and spermatogenic cells characterized with a monoclonal antibody. Int. J. Androl. 7, 283-296.

Koehler, J.K. (1975) Periodicities in the acrosome or acrosomal membrane: some observations on mammalian spermatozoa. In The Biology of the Male Gamete, pp. 337-342. Eds J. G. Duckett \& P. A. Racey. Academic Press, London.

Koehler, J.K. (1981) Lectins as probes of the spermatozoon surface. Archs Androl. 6, 197-217.

Köhler, G. \& Milstein, C. (1975) Continuous cultures of fused cells secreting antibody of predefined specificity. Nature, Lond. 256, 495-497.

Laemmli, U.K. (1970) Cleavage of structural proteins during the assembly of the head of bacteriophage T4. Nature, Lond. 227, 680-685.

Lane, D. \& Koprowsky, H. (1982) Molecular recognition and the future of monoclonal antibodies. Nature, Lond. 296, 200-202.

Lee, C.-Y.G., Huang, Y.-S., Huang, C.-H., Hu, P.-C. \& Menge, A.C. (1982) Monoclonal antibodies to human sperm antigens. J. Reprod. Immunol. 4, 173-181.

Mettler, L., Paul, S., Baukloh, V. \& Feller, A.C. (1984) Monoclonal sperm antibodies: their potential for investigation of sperms as target of immunological contraception. Am. J. Reprod. Immunol. 5, 125-128.

Naz, R.K., Alexander, N.J., Isahakia, M. \& Hamilton, M.S. (1984) Monoclonal antibody to a human germ cell membrane glycoprotein that inhibits fertilization. Science, N.Y. 225, 342-344.

Noda, Y.D. \& Yanagimachi, R. (1976) Electron microscopic observations of guinea pig spermatozoa penetrating eggs in vitro. Dev. Growth Diff. 18, 15-23.

C'Rand, M.G. (1982) Modification of the sperm membrane during capacitation. Ann. N.Y. Acad. Sci. 383, 392-404. 
Oriol, R. \& Mancilla-Jimenez, R. (1983) Fluorescent staining of nuclei and amyloid substance. Two useful properties of $p$-phenylenediamine. J. Immunol. Meth. 62, 185-192.

Primakof,, P. \& Myles, D.G. (1983) A map of the guinea pig sperm surface constructed with monoclonal antibodies. Devl Biol. 98, 417-428.

Shinohara, H., Yanagimachi, R. \& Srivastava, P.N. (1985) Enhancement of the acrosome reaction of hamster spermatozoa by the proteolytic enzymes, kallikrein, trypsin, and chymotrypsin. Gamete Res. 11, 19-28.

Singer, S.J. (1982) Molecular interactions at the cell surface. In Membrane and Genetic Disease, pp. 3-24. Eds J. R. Sheppard, V. E. Anderson \& J. W. Eaton. Alan R. Liss, Inc., New York.

Stambaugh, R. (1978) Enzymatic and morphological events in mammalian fertilization. Gamete Res. 1, 65-85.

Tea, N.T., Jondet, M. \& Scholler, R. (1983) A 'Migrationgravity sedimentation' method for collecting motile spermatozoa from human semen. In In vitro Fertilization, Embryo Transfer and Early Pregnancy, pp.117-120. Eds R. F. Harrison, J. Bonnar \& W. Thompson. MTP Press Ltd, Lancaster.

Thorpe, R.; Bird, C.R. \& Spitz, M. (1984) Immunoblotting with monoclonal antibodies: loss of immunoreactivity with human immunoglobulins arises from polypeptide chain separation. J. Immunol. Meth. 73, 259-265.
Van Ewijk, W., Van Soest, P.L., Verkerk, A. \& Jongkind, J.F. (1984) Loss of antibody binding to prefixed cells: fixation parameters for immunocytochemistry. Histochem. J. 16, 179-193.

Villarroya, S. \& Scholler, R. (1984) Localization of human sperm antigens with monoclonal antibodies. Path. Biol., Paris 32, 832-834.

Walker, W.S., Beelan, R.H.J., Buckley, P.J., Melvin, S.L. \& Yen, S.-E. (1984) Some fixation reagents reduce or abolish the detectability of Ia-antigen and HLA-DR on cells. J. Immunol. Meth. 67, 89-99.

Wolf, D.P., Sokoloski, J.E., Dandekar, P. \& Bechtol, K.B. (1983) Characterization of human sperm surface antigens with monoclonal antibodies. Biol. Reprod. 29, 713-723.

Yan, Y.C., Wang, L.F., Sato, E. \& Koide, S.S. (1983) Monoclonal antibody inducing human sperm agglutination. Am. J. Reprod. Immunol. 4, 111-115.

Yanagimachi, R. (1981) Fertilization and embryonic development in vitro. In Mechanisms of Fertilization in Mammals, pp. 82-182. Eds L. Mastroianni, Jr \& J. D. Biggers, Plenum Press, New York.

Yanagimachi, R., Noda, Y.D., Fujimoto, M. \& Nicolson, G.L. (1972) The distribution of negative surface charges on mammalian spermatozoa. Am. J. Anat. $135,497-520$. 